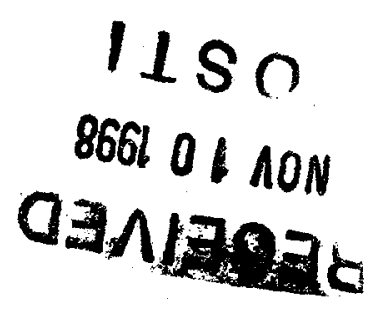

\title{
Technology Assessment of Dust Suppression Techniques Applied During Structural Demolition
}

\author{
Final Report \\ August 6, 1997 \\ By: \\ M. A. Ebadian \\ Joseph F. Boudreaux; S. K. Dua
}

Work Performed Under Contract No.: DE-FG21-95EW55094

For

U.S. Department of Energy

Office of Fossil Energy

Federal Energy Technology Center

P.O. Box 880

Morgantown, West Virginia 26507-0880

By

Florida International University

Hemispheric Center for Environmental Technology (HCET)

Center for Engineering \& Applied Sciences

10555 West Flagler Street

EAS-2100

Miami, Florida 33174 


\section{Disclaimer}

This report was prepared as an account of work sponsored by an agency of the United States Government. Neither the United States Government nor any agency thereof, nor any of their employees, makes any warranty, express or implied, or assumes any legal liability or responsibility for the accuracy, completeness, or usefulness of any information, apparatus, product, or process disclosed, or represents that its use would not infringe privately owed rights. Reference herein to any specific commercial product, process, or service by trade name, trademark, manufacturer, or otherwise does not necessarily constitute or imply its endorsement, recommendation, or favoring by the United States Government or any agency thereof. The views and opinions of authors expressed herein do not necessarily state or reflect those of the United States Government or any agency thereof. 


\section{DISCLAIMER}

Portions of this document may be illegible in electronic image products. Images are produced from the best available original document. 


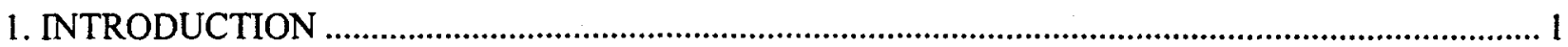

1.1 BACKGROUND OF THE PROBLEM

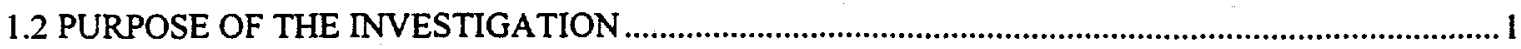

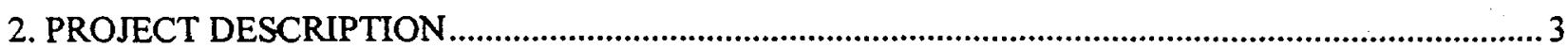

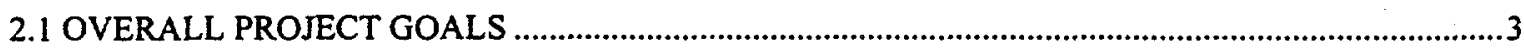

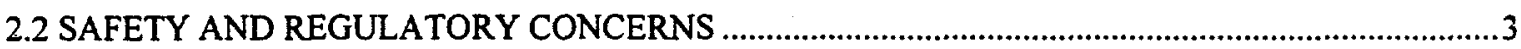

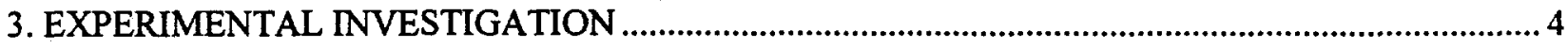

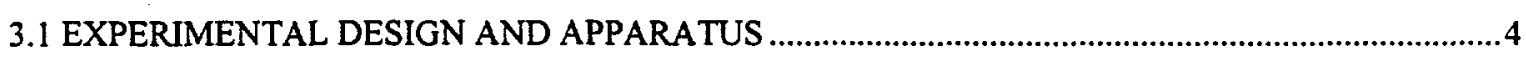

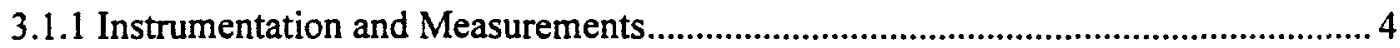

3.1.2 Aerosol Dust Abatement Methods ..................................................................... 5

3.1.3 Test Surrogate Selection and Preparation.................................................................... 7

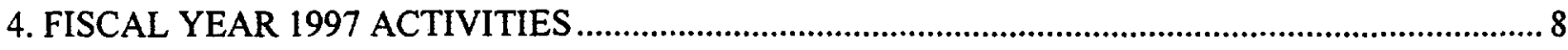

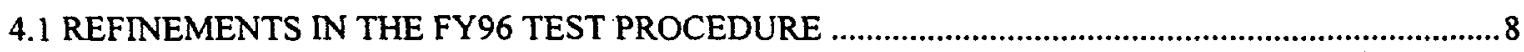

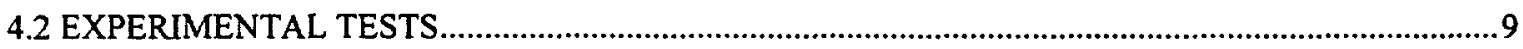

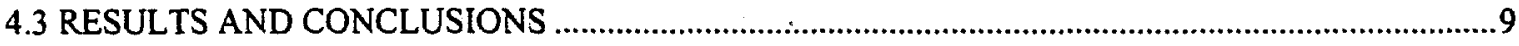

4.3.1 Particle Number and Size Distribution.......................................................... 12

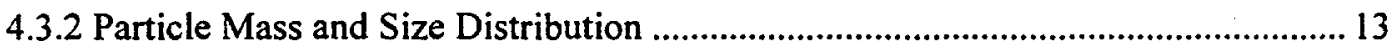

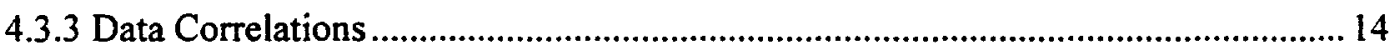

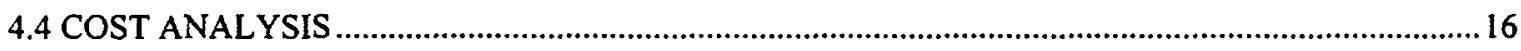

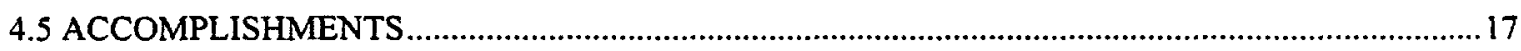

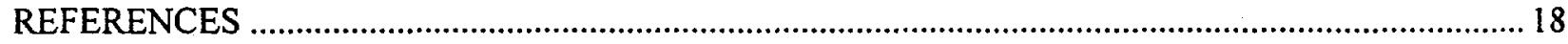

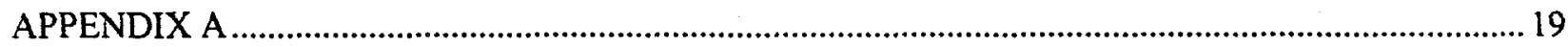

Table Al. Cost Analysis for Dust Suppression ....................................................................................... 19 


\section{LIST OF TABLES}

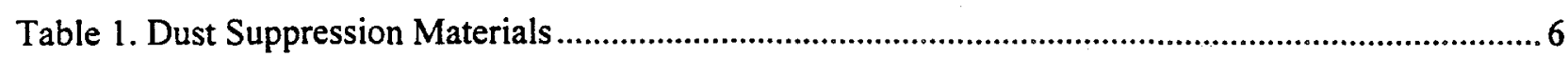

Table 2. Effectiveness of Different Agents in Dust Suppression.

10

Table 3. Ratio of Number of Particles of a Given Size Interval to the Total Number of Particles (Size $\geq 0.3 \mu \mathrm{m}$ ). 11

Table 4. Dust Suppression for Different Agents Tested in Various Size Ranges . 12 


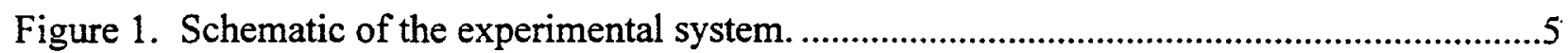

Figure 2. Hollow concrete block plastered on two surfaces. ..................................................

Figure 3. Particle size distribution by number for the hollow concrete surrogates with no-suppression conditions.

Figure 4. Particle size distribution by mass for the hollow concrete surrogates with no-suppression conditions.

Figure 5. Mathematical correlation for particle number for the hollow concrete surrogates with no-suppression conditions

Figure 6. Mathematical correlation for particle mass for the hollow concrete surrogates with no-suppression conditions. 


\section{INTRODUCTION}

\subsection{BACKGROUND OF THE PROBLEM}

Nationwide, the United States Department of Energy (DOE) owns hundreds of buildings that have reached the end of their useful life and are destined to be demolished. As these buildings undergo demolition, many non-nuclear technologies are being adapted to the nuclear decontamination and decommissioning (D\&D) industry. Factors such as dust generation and health and safety are major concerns when these technologies are applied to building D\&D. These factors must be addressed before D\&D begins. In order to demolish a structure properly and at the same time control the amount of dust generated by the given technology, an evaluation must be conducted to choose the most appropriate technology for the task.

Dust suppression is the practice of controlling the amount of particulate matter suspended in air. Dust control is important during remediation because the inhalation of dust aerosol particles (< $10 \mu \mathrm{m}$ diameter) is considered a health risk. These particles may also contain contaminants that present a threat to the environment.

The generation of dust is typically a function of moisture content, the amount of energy delivered to the surface (such as wind or drop height), and the fraction of the surface that is easily entrained into the air. Therefore, the abatement of dust generation requires the control of one or more of these factors. The main parameters that must be controlled during decontamination and decommissioning activities are the moisture content and the fraction of the surface that is easily entrained in the air. This can be achieved through the use of water sprays, mists, fogs, foams, or suitable crusting agents.

\subsection{PURPOSE OF THE INVESTIGATION}

Hanford, Fernald, Savannah River, and other sites are currently reviewing technologies that can be implemented to demolish buildings in a cost-effective manner. In order to demolish a structure and, at the same time, minimize the amount of dust generated by a given technology, an evaluation must be conducted to choose the most appropriate dust suppression technology.

Thus, the purpose of this research, which was conducted by the Hemispheric Center for Environmental Technology (HCET) at Florida International University (FIU), was to perform an experimental study of dust aerosol abatement (dust suppression) methods as applied to nuclear D\&D. This experimental study specifically targeted the problem of dust suppression during demolition. The resulting data were used in the development of mathematical correlations that can be applied to structural demolition. In the Fiscal Year 1996 (FY96), the effectiveness of different dust suppressing agents was investigated for different types of concrete blocks. Initial tests were conducted in a broad particle size range.

In Fiscal Year 1997 (FY97), additional tests were performed in the size range in which most of the particles were detected. Since particle distribution is an important parameter for predicting deposition in various compartments of the human respiratory tract, various tests were aimed at 
determining the particle size distribution of the airborne dust particles. The effectiveness of dust suppressing agents for particles of various size was studied. Instead of conducting experiments on various types of blocks, it was thought prudent to carry out additional tests on blocks of the same type. Several refinements were also incorporated in the test procedures and data acquisition system used in FY96. 


\section{PROJECT DESCRIPTION}

\subsection{OVERALL PROJECT GOALS}

This report details the results attained in FY97. The aims of the research conducted under this project as well as the status of the various tasks are presented below:

Task 1: Complete literature review of technologies that perform structural demolition as well as those that perform dust suppression (completed in FY96);

Task 2: Development of a test plan to complete a detailed analysis of dust suppression techniques (completed in FY96);

Task 3: Selection and acquisition of technologies to perform a detailed analysis of dust suppression techniques (initiated in FY96 and completed in FY97);

Task 4: Laboratory testing of promising dust suppression technologies (initiated in FY96; refinement were made and the tests were completed in FY97);

Task 5: Development of extrapolation factors to be applied to building D\&D for dust suppression techniques (initiated in FY96; completed in FY97); and

Task 6: Cost estimates of different dust suppression methods (completed in FY97).

\subsection{SAFETY AND REGULATORY CONCERNS}

The regulatory policies that apply to the control of dust aerosols during dismantlement are those standards set by the following regulations and guidelines:

- National Institute of Occupational Safety and Health (NIOSH) regulations for abating dust aerosols to levels of $<10 \mathrm{mg} / \mathrm{m}^{3}$ for total aerosol mass;

- The Clean Air Act of 1990 for air quality to protect the public health and welfare and the use of quality standards and criteria for the control of pollutants in the environment; and

- The Clean Water Act 1990 to control the levels of effluents containing toxic and hazardous pollutants. 


\section{EXPERIMENTAL INVESTIGATION}

\subsection{EXPERIMENTAL DESIGN AND APPARATUS}

Experiments for the abatement of dust aerosols during demolition were conducted in the Decontamination and Decommissioning Laboratory at the Hemispheric Center for Environmental Technology at the Florida International University (FIU- HCET). The test chamber (inner dimensions $4.92 \mathrm{ft}$. $\times 4.04 \mathrm{ft} . \times 6.97 \mathrm{ft}$.) used to measure the dust particles was constructed of an acrylic glass structure supported by a wood base with an aluminum covering. Inlet and outlet ventilation ports were cut into the sides of the test chamber to facilitate the passage of air through the chamber. The ventilation ports were fitted with particulate air filters to allow only filtered air into the chamber. Attached near the top right side of the test chamber was an exhaust fan that allowed for the passage of air from the test environment to simulate the effects of wind during the demolition process. The exhaust fan produced 50 air changes per hour. The air inlet port was on the side opposite the outlet port.

Inside the chamber, there was an impact device that was composed of a composite structure of various metals such as steel, pig iron, and aluminum. The base of the impact device and the superstructure were constructed mainly of aluminum to maintain a minimum weight during the changing of the test weights. The superstructure was braced and bolted to the bottom of the structure and the aluminum plate to absorb any moments generated during the release of the test weights. This was done to prevent bending forces from transmitting any excessive vibrational forces experienced during impact.

The test weights were made of steel blocks. These were fitted with linear bearings bolted on two sides. The bearings ensured that proper linear motion would be achieved during the impact of the test weights on the concrete surrogates during the simulated demolition conditions. The weights were raised using a hand-operated mechanical winch that was attached to a release lever at the top of test chamber. This release mechanism allowed for the free fall of each test weight.

\subsubsection{Instrumentation and Measurements}

A Hiac/Royco MicroAir model \#5230 airborne particle counter was used to measure particle distributions. The counter features a built-in timing function that enables it to turn off and on automatically during sampling, depending on the time period selected by the equipment operator. The dust particle distribution is obtained when the dust particles are pulled into the air sampling probe through a diffuser type inlet. As the dust particles enter the sampling probe, they scatter a laser beam light which triggers a built-in sensor. The sensor converts the light into electrical pulses whose amplitude is proportional to the particle size. The particle counter has the ability to measure particles in eight size channels within a range of 0.3 to $230 \mu \mathrm{m}$. Experimental readings were taken at $0.3,0.5,0.7,1.0,2.0,4.0,7.0$ and $10.0 \mu \mathrm{m}$, considering that hardly any particles were generated beyond this size. The experimental setup used to perform the tests on the concrete surrogates is shown in Figure 1. 


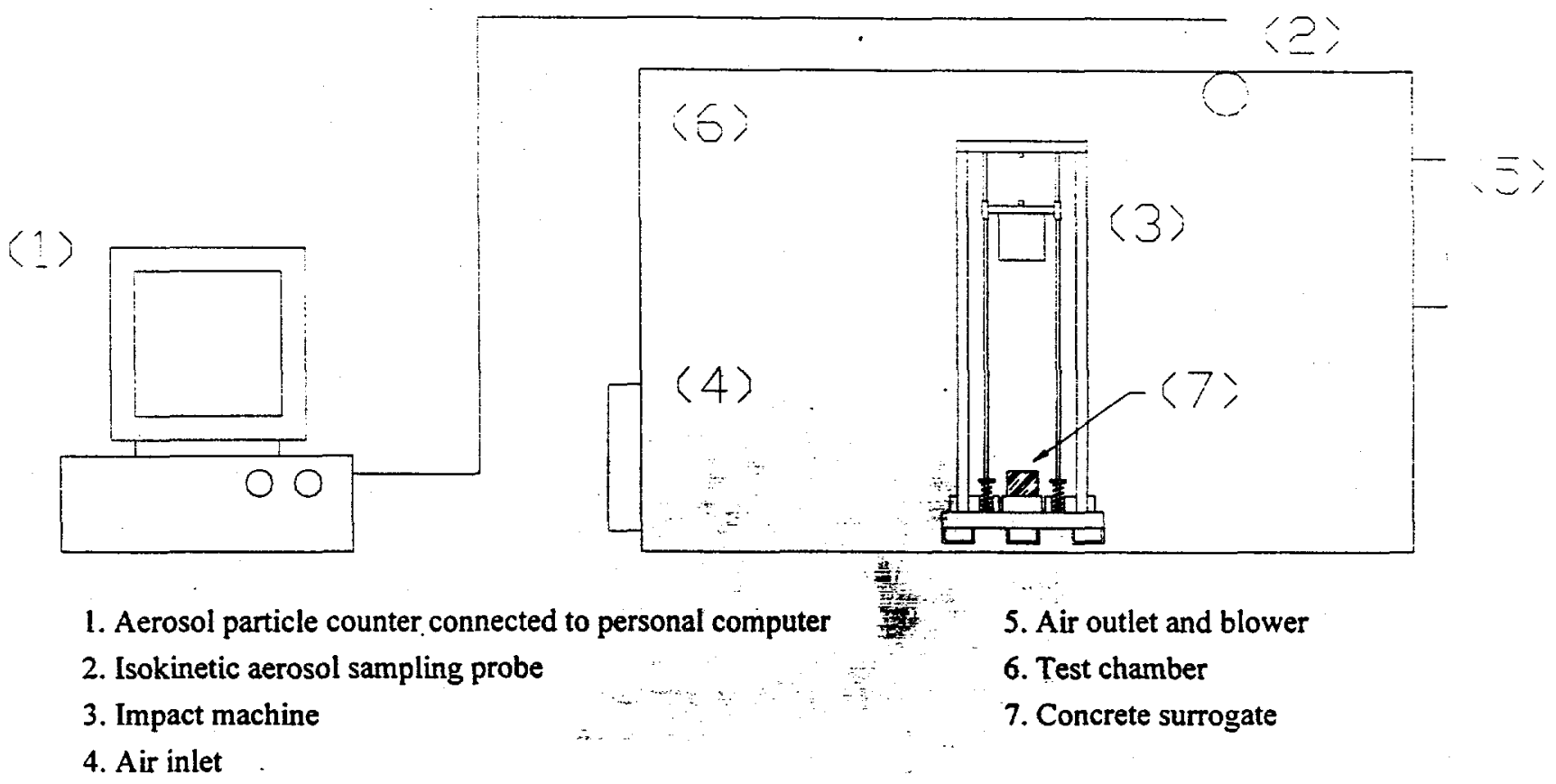

Figure 1. Schematic of the experimental system.

\subsubsection{Aerosol Dust Abatement Methods}

The literature survey and personal communications revealed that the principal dust suppressing agents used in DOE Complex and in industry were the Polymeric Barrier System, Coherex, water, and water with a surfactant. Table 1 presents the details of the materials used for dust suppression as well their methods of application.

Tests were conducted with and without dust suppressing agents. Tests without a dust suppression agent applied on the concrete surrogates were performed to obtain baseline data for comparison with the data resulting from the investigation of dust suppression methods. Comparison of each method to the baseline data provided insight into the magnitude or degree of particulate reduction that was obtained after each dust suppression method was applied. 


\section{Table 1. \\ Dust Suppression Materials}

\begin{tabular}{|c|c|c|c|}
\hline Materials & Description of the Material & Supplier & $\begin{array}{l}\text { Method of Application on } \\
\text { Concrete Surrogates }\end{array}$ \\
\hline $\begin{array}{l}\text { Polymeric Barrier } \\
\text { System }\end{array}$ & $\begin{array}{l}\text { Crusting agents have the potential } \\
\text { of decreasing the fraction of the } \\
\text { surface that is easily entrained into } \\
\text { air. This suppression agent comes } \\
\text { in a solution form consisting of } \\
62 \% \text { polymer plus a proprietary } \\
\text { mixture, } 38 \% \text { water, and } \\
\text { formaldehyde. }\end{array}$ & $\begin{array}{l}\text { Bartlett Services, Inc. } \\
60 \text { Industrial Park Road } \\
\text { PO Box } 1800 \\
\text { Plymouth, MA } 02360\end{array}$ & $\begin{array}{l}\text { The polymeric barrier material } \\
\text { was applied using a household } \\
\text { paint brush. }\end{array}$ \\
\hline $\begin{array}{l}\text { Coherex brushed } \\
\text { and dried } \\
\text { (Coherex-to-water } \\
\text { ratio: } 1: 4 \text { ) }\end{array}$ & \multirow{3}{*}{$\begin{array}{l}\text { Coherex is a stable, concentrated, } \\
\text { nonvolatile water emulsion, } \\
\text { consisting of } 60 \% \text { petroleum resins } \\
\text { and } 40 \% \text { wetting agent. The resin is } \\
\text { not water soluble and will not leach } \\
\text { out. Coherex aids in the reduction } \\
\text { of water tension as a droplet } \\
\text { adheres to the surface of the } \\
\text { material. }\end{array}$} & \multirow{3}{*}{$\begin{array}{l}\text { Witco Corporation } \\
\text { Golden Bear Division } \\
10100 \text { Santa Monica Blvd. } \\
\text { Los Angeles, CA } 90067\end{array}$} & $\begin{array}{l}\text { The Coherex-water solution was } \\
\text { applied using a household paint } \\
\text { brush. The concrete surrogates } \\
\text { were allowed to dry completely. }\end{array}$ \\
\hline \begin{tabular}{|l|} 
Coherex soaked \\
and dried \\
(Coherex-to-water \\
ratio: $1: 10$ )
\end{tabular} & & & $\begin{array}{l}\text { The Concrete surrogates were } \\
\text { fully immersed for } 5 \text { minutes in } \\
\text { a Coherex-water mixture and } \\
\text { set to dry completely. }\end{array}$ \\
\hline \begin{tabular}{|l|} 
Coherex soaked \\
(Coherex-to-water \\
ratio: $1: 10)$
\end{tabular} & & & $\begin{array}{l}\text { The Concrete surrogates were } \\
\text { fully immersed for } 5 \text { minutes in } \\
\text { a Coherex-water mixture and } \\
\text { then placed on the test platform } \\
\text { for } 5 \text { minutes before conducting } \\
\text { the test. }\end{array}$ \\
\hline Water soaked & Tap water & $\begin{array}{l}\text { Miami-Dade Water and } \\
\text { Sewer Department }\end{array}$ & $\begin{array}{l}\text { The Concrete surrogates were } \\
\text { fully immersed for } 5 \text { minutes in } \\
\text { tap water and then placed on the } \\
\text { test platform for } 5 \text { minutes } \\
\text { before conducting the test. }\end{array}$ \\
\hline Water sprayed & Tap water & $\begin{array}{l}\text { Miami-Dade Water and } \\
\text { Sewer Department }\end{array}$ & $\begin{array}{l}\text { Water was sprayed from the } \\
\text { start of the test until the dust } \\
\text { concentration was close to } \\
\text { ambient level. }\end{array}$ \\
\hline Soap soaked & TIDE soap & $\begin{array}{l}\text { Procter \& Gamble Corp. } \\
\text { Cincinnati, OH } 45202\end{array}$ & $\begin{array}{l}\text { 3.1 lb. of liquid soap was mixed } \\
\text { in } 9.51 \text { gal of tap water. } \\
\text { Concrete surrogates were } \\
\text { immersed in the soap-water } \\
\text { mixture for } 5 \text { minutes and then } \\
\text { placed on the test platform for } 5 \\
\text { minutes before conducting the } \\
\text { test. }\end{array}$ \\
\hline
\end{tabular}




\subsubsection{Test Surrogate Selection and Preparation}

During FY97, additional tests were conducted on 100 hollow concrete blocks. These blocks were of the same type as those used in FY96. Their outer dimensions wers 15.5" $\times 7.5$ " $\times 7.5$ ". These blocks are used mainly for external structural support.

Figure 2 presents a sketch of a protypical block used as a test surrogate. The blocks were mortared 0.25 " on two surfaces, the hollow $15.5 " \times 7.5$ " side and the solid $7.5 " \times 7.5$ " side. In actual construction work, mortar is applied on four surfaces at the block seams. However, during demolition all four surfaces are never exposed. Therefore, the mortaring of two surfaces was considered to approximate actual conditions.

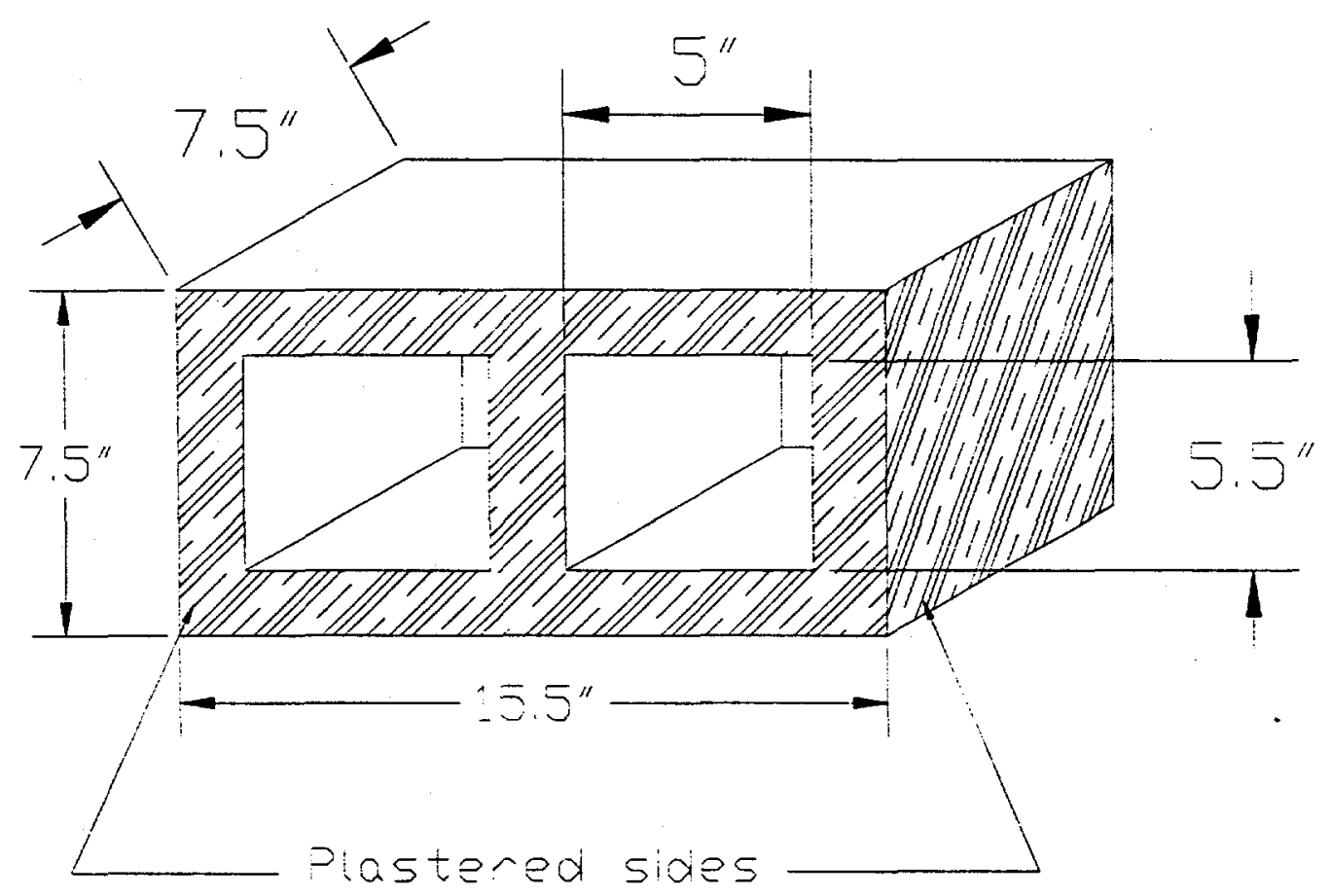

Figure 2. Hollow concrete block plastered on two surfaces. 


\section{FISCAL YEAR 1997 ACTIVITIES}

\subsection{REFINEMENTS IN THE FY96 TEST PROCEDURE}

One hundred additional tests were performed as a part of the experimental work conducted in FY97. During the course of the experimentation, each of the concrete surrogates used was strategically placed in the center of the impact device base in order to ensure that the test weights would impact each surrogate at the same location. This refinement was incorporated to ensure consistency in the experimental procedure during data gathering.

The test weights simulated the forces that are applied when a concrete block falls from the top position of a concrete wall during structural demolition. A 100 pound $(45.37 \mathrm{~kg})$ impact load was applied to the test surrogates during the course of the experiments. It was dropped from three heights, thus imparting different impact momenta $875 \mathrm{lb} . \mathrm{ft} . \mathrm{s}^{-1}$ to $1330 \mathrm{lb} . \mathrm{ft} . \mathrm{s}^{-1}$ (121 kg.m.s $\mathrm{s}^{-1}$ to $184 \mathrm{~kg} \cdot \mathrm{m} \cdot \mathrm{s}^{-1}$ ) representing different wall heights generally encountered during the decommissioning of a facility.

The following refinements were made in the test procedure and data acquisition system:

- The acrylic test chamber was lined with aluminum foil on all internal surfaces except for a small viewing window to minimize the effect of electrostatic forces on particle collection;

- A Hiac/Royco particle counter, used to measure the number of particles generated during the breaking of a block, was calibrated (the counter measures particles in unit volume of air, and from this measurement total particles in the test chamber can be calculated). The Data Logger software was installed and used for the continuous measurement of dust concentration in the test chamber as well as for data retrieval for further processing;

- The concrete block was placed on fixed and spaced wooden supports such that the base of the block was always at the same height from the floor;

- A 100-lb. (45.37 kg) iron mass was dropped from a fixed height so that it always attained the same velocity when it hit the block;

- Before starting the next test, the test chamber was cleaned of the broken pieces of concrete and dust. The dust concentration in the chamber air was brought to a negligible value;

- With the exhaust fan running, particle concentration in the test chamber was measured before breaking each block. This measurement was subtracted from that obtained in the test to arrive at the net concentration due to the breaking of the blocks. Particle concentration was measured continuously from the time the blocks were broken. The run time for each recorded concentration was 15 seconds. During this time, the particle concentration increases initially, reaches a maximum value, and then decreases continuously. The fitted slope of the concentration-time graph was used to arrive at the maximum concentration at the time the maximum value was recorded. 


\subsection{EXPERIMENTAL TESTS}

To study the effectiveness of various dust suppressing agents, tests were conducted with different suppressing agents applied to the surrogate. The concentration of dust generated as a result of breaking these surrogate was measured and compared to the concentration of dust generated when no suppressing agent was applied. In order to ensure that the surrogates were identical, that their conditions had not changed with time, and that the data were reproducible, no-suppression tests were performed on the same days the dust suppression tests were conducted. Additional tests at different heights of the iron mass, representing different fall heights or different loads, were also performed. The tests were conducted under the following blocks treatment conditions (the number of tests performed under each condition is given in the parentheses).

- No suppressing agent applied on the blocks. Tests were repeated on different days to verify the reproducibility of the dust concentration and for comparison with the dust suppression conditions (25 tests);

- Blocks coated with the Polymeric Barrier System using a brush and then allowed to dry for three days (10 tests);

- Blocks coated with the Coherex-water mixture (1:4) using a brush and then allowed to dry for a one week ( 7 tests);

- Blocks immersed in the Coherex-water mixture (1:10) for five minutes and then allowed to dry for a week (6 tests);

- Blocks immersed in the Coherex-water mixture $(1: 10)$ for five minutes and then placed on wooden supports for five minutes before breaking (10 tests);

- Blocks immersed in water for five minutes and then placed on wooden supports for five minutes before breaking (14 tests);

- Blocks immersed in surfactant for five minutes and then placed on wooden supports for five minutes before breaking ( 10 tests);

- Water sprayed on the blocks at a rate of $7.471 \mathrm{~min}^{-1}$ using a shower head. The water was sprayed from the time the blocks were broken until the dust concentration was close to the ambient level ( 7 tests);

- No suppressing agent applied on the blocks; falling mass kept constant. The mass was dropped from different heights to study the influence of different impacts on dust generation (10 tests); and

- No suppressing agent applied on the blocks to determine particle size distribution. The particle counter was operated in specially selected particle size ranges (4 tests).

\subsection{RESULTS AND CONCLUSIONS}

Table 2 presents the total number of particles generated in different size beginning with $0.3 \mu \mathrm{m}$ under various test conditions. From the data, the effectiveness of the various agents in 
suppressing dust was determined as compared to the condition when no suppressing agent was applied. The following conclusions have been drawn:

1. Each dust suppressing condition reduces dust concentration to some degree;

2. Dust suppression is higher in wet conditions than in dry conditions. For example, dust suppression performance is enhanced when blocks are immersed in Coherex and broken than when they are immersed and dried before breaking; and

3. Three methods, namely, immersion in a surfactant, immersion in the Coherex-water mixture (1:10), and water spraying with a shower head, are found to be more efficient in dust reduction as compared to the other agents and methods of application. These three methods reduced the dust concentration from 69 to 79 percent.

Table 2.

Effectiveness of Different Agents in Dust Suppression

\begin{tabular}{|l|c|c|c|}
\hline \multicolumn{1}{|c|}{ Test Condition } & $\begin{array}{c}\text { Number of } \\
\text { Particles }\end{array}$ & $\begin{array}{c}\text { Relative } \\
\text { Standard } \\
\text { Deviation (\%) }\end{array}$ & $\begin{array}{c}\text { Dust } \\
\text { Suppression } \\
\text { (\%) }\end{array}$ \\
\hline No suppression & $1.95 \mathrm{E}+09$ & 31.6 & \\
\hline Polymeric Barrier System & $8.64 \mathrm{E}+08$ & 39.9 & 55.6 \\
\hline Coherex (1) water (4) mixture brushed and dried & $1.06 \mathrm{E}+09$ & 54.2 & 45.5 \\
\hline Coherex (1) water (10) mixture soaked and dried & $1.28 \mathrm{E}+09$ & 34.7 & 34 \\
\hline Coherex (1) water (10) mixture soaked & $4.19 \mathrm{E}+08$ & 33.2 & 78.5 \\
\hline Water soaked & $7.94 \mathrm{E}+08$ & 55.4 & 59.2 \\
\hline Water sprayed & $6.00 \mathrm{E}+08$ & 31.5 & 69.2 \\
\hline Surfactant solution & $4.14 \mathrm{E}+08$ & 43.9 & 78.7 \\
\hline
\end{tabular}

Table 3 presents the ratios of the number of particles in different size ranges to the total number of particles $0.3 \mu \mathrm{m}$ and above in size for various test conditions. It was observed that for smaller sizes, this ratio was marginally higher in wet dust suppression conditions than in dry conditions, suggesting that wet conditions suppress large-sized particles relatively more efficiently than small-sized particles. Knowledge of the ratio of the number (as well as mass) of particles in different size ranges is important in determining inhalation exposure because the fraction of the aerosol particles depositing in the human respiratory tract depends on the size of the inhaled particles. 
Table 3.

Ratio of Number of Particles in a Given Size Interval to the

Total Number of Particles (Size $\geq \mathbf{0 . 3} \boldsymbol{\mu m}$ )

\begin{tabular}{|c|c|c|c|c|c|c|c|c|}
\hline \multirow{2}{*}{$\begin{array}{c}\text { Particle } \\
\text { Size } \\
(\mu \mathrm{m})\end{array}$} & \multirow{2}{*}{$\begin{array}{c}\text { Ratio } \\
\text { and } \\
\text { RSD* } \\
(\%)\end{array}$} & \multicolumn{7}{|c|}{ Test Conditions } \\
\hline & & $\begin{array}{c}\text { No } \\
\text { Suppression }\end{array}$ & $\begin{array}{l}\text { Polymeric } \\
\text { Barrier } \\
\text { System }\end{array}$ & $\begin{array}{c}\text { Coherex } \\
\text { Brushed and } \\
\text { Dried }\end{array}$ & $\begin{array}{c}\text { Coherex } \\
\text { Soaked and } \\
\text { Dried }\end{array}$ & $\begin{array}{l}\text { Coherex } \\
\text { Soaked }\end{array}$ & $\begin{array}{l}\text { Water } \\
\text { Soaked }\end{array}$ & $\begin{array}{c}\text { Soap } \\
\text { Soaked }\end{array}$ \\
\hline \multirow[b]{2}{*}{$\begin{array}{c}0.30 \text { to }< \\
0.50\end{array}$} & Ratio & 0.3104 & 0.3625 & 0.3264 & 0.3570 & 0.3777 & 0.3817 & 0.3635 \\
\hline & RSD & 8.2 & 9.2 & 5.2 & 6.5 & 3.0 & 6.7 & 18.2 \\
\hline \multirow[b]{2}{*}{$\begin{array}{c}0.5 \text { to }< \\
0.70\end{array}$} & Ratio & 0.1544 & 0.1603 & 0.1559 & 0.1639 & 0.1749 & 0.1753 & 0.1764 \\
\hline & RSD & 2.6 & 3.3 & 2.9 & 1.5 & 4.1 & 2.8 & 4.1 \\
\hline \multirow[b]{2}{*}{$\begin{array}{c}0.70 \text { to }< \\
1.00\end{array}$} & Ratio & 0.0933 & 0.0915 & 0.0924 & 0.0937 & 0.0988 & 0.0976 & 0.1001 \\
\hline & RSD & 2.4 & 1.8 & 1.9 & 2.2 & 2.7 & 2.9 & 6.2 \\
\hline \multirow[b]{2}{*}{$\begin{array}{c}1.00 \text { to }< \\
2.00\end{array}$} & Ratio & 0.1949 & 0.1808 & 0.1907 & 0.1841 & 0.1842 & 0.1822 & 0.1900 \\
\hline & RSD & 4.1 & 5.3 & 2.4 & 3.6 & 2.3 & 5.1 & 12.3 \\
\hline \multirow{3}{*}{$\begin{array}{c}2.00 \text { to }< \\
4.00\end{array}$} & Ratio & 0.2124 & 0.1786 & 0.2017 & 0.1770 & 0.1495 & 0.1490 & 0.1547 \\
\hline & RSD & 7.7 & 12.7 & 6.7 & 7.9 & 8.4 & 11.4 & 23.5 \\
\hline & Ratio & 0.0291 & 0.0220 & 0.0272 & 0.0206 & 0.0128 & 0.0122 & 0.0129 \\
\hline $\begin{array}{c}4.00 \text { to }< \\
7.00\end{array}$ & RSD & 17.3 & 21.0 & 14.9 & 13.7 & 11.8 & 23.2 & 28.9 \\
\hline \multirow[b]{2}{*}{$\begin{array}{c}7.00 \text { to }< \\
10.00\end{array}$} & Ratio & 0.0051 & 0.0040 & 0.0050 & 0.0035 & 0.0019 & 0.0018 & 0.0021 \\
\hline & RSD & 19.9 & 24.2 & 21.0 & 19.0 & 15.8 & 29.3 & 37.2 \\
\hline \multirow[b]{2}{*}{$\geq 10.00$} & Ratio & 0.0005 & 0.0003 & 0.0006 & 0.0003 & 0.0001 & 0.0001 & 0.0003 \\
\hline & RSD & 24.9 & 34.8 & 36.5 & 33.8 & 71.1 & 24.2 & $\overline{5 t}$ \\
\hline
\end{tabular}

* Relative Standard Deviation 
The dust suppression capability of different suppression agents for various particle sizes is shown in Table 4. It can be observed that the dust suppression efficiency increases significantly with particle size. It should be noted that this table does not display data for the showering case inasmuch as these experiments were performed in a slightly different size range. However, the trend of increased efficiency in dust suppression with particle size was also clear in this case.

Table 4.

Dust Suppression Efficiency of the Different Agents Tested in Various Size Ranges

\begin{tabular}{|c|c|c|c|c|c|c|c|}
\hline \multirow{2}{*}{$\begin{array}{c}\text { Particle } \\
\text { Size Range } \\
\text { in } \mu \mathrm{m}\end{array}$} & $\begin{array}{c}\text { Number of } \\
\text { Particles in } \\
\text { Size Range } \\
\text { for No } \\
\text { Suppression }\end{array}$ & $\begin{array}{c}\text { Polymeric } \\
\text { Barrier } \\
\text { Suppression }\end{array}$ & $\begin{array}{c}\text { Coherex } \\
\mathbf{1 : 4} \\
\text { (Brushed } \\
\text { and Dried) }\end{array}$ & $\begin{array}{c}\text { Coherex } \\
\mathbf{1 : 1 0} \\
\text { (Soaked } \\
\text { and Dried) }\end{array}$ & $\begin{array}{c}\text { Coherex } \\
\mathbf{1} 10 \\
\text { (Soaked) }\end{array}$ & $\begin{array}{c}\text { Water } \\
\text { (Soaked) }\end{array}$ & $\begin{array}{c}\text { Soap } \\
\text { (Soaked) }\end{array}$ \\
\hline $0.3-0.5$ & 1306601 & 44.8 & 38.5 & 27.6 & 66.3 & 23.0 & 74.2 \\
\hline $0.5-0.7$ & 654254 & 52.0 & 41.1 & 34.3 & 69.2 & 29.0 & 75.4 \\
\hline $0.7-1.0$ & 395832 & 55.0 & 42.4 & 38.3 & 71.1 & 34.3 & 76.9 \\
\hline $1.0-2.0$ & 827801 & 58.1 & 43.5 & 42.5 & 74.2 & 41.2 & 79.1 \\
\hline $2.0-4.0$ & 898869 & 62.7 & 45.1 & 49.4 & 80.4 & 54.9 & 84.3 \\
\hline $4.0-7.0$ & 123259 & 67.4 & 45.9 & 57.7 & 87.8 & 73.1 & 90.4 \\
\hline $7.0-10.0$ & 21403 & 66.2 & 42.4 & 58.6 & 89.6 & 78.0 & 91.0 \\
\hline
\end{tabular}

\subsubsection{Particle Number and Size Distribution}

Particles in nature follow a log-normal size distribution (Mercer 1973), that is, a graph of the number (or fractional number) of particles per unit logarithmic size interval (on the vertical axis) and the logarithm of particle size (on the horizontal axis) should exhibit a normal distribution with a number median diameter (NMD) and a geometric standard deviation (GSD).

A particle size distribution curve for a no-suppression condition is presented in Figure 3 . The horizontal axis shows particle diameter in $\mu \mathrm{m}$. This axis has a natural logarithmic scale. The vertical axis shows the fractional number of particles per unit logarithmic size interval. For example, if $\mathrm{N}$ is the fraction of the total (or fractional) number of particles in size intervals $\mathrm{D}_{i}$ and $\mathrm{D}_{\mathrm{i}+1}$, the vertical axis represents $\mathrm{N} /\left(\ln \mathrm{D}_{\mathrm{i}+1}-\ln \mathrm{D}_{\mathrm{i}}\right)$. The corresponding point on the horizontal axis is $\sqrt{ }\left(D_{i} \times D_{i+1}\right)$. The particle size distribution was observed to be bimodal. The first peak occurred at a particle size of $0.3 \mu \mathrm{m}$ or smaller. It may be noted that the lowest size detection limit of the particle counter is $0.3 \mu \mathrm{m}$. Therefore, the counter provides no information for particles smaller than $0.3 \mu \mathrm{m}$, and it is not possible to determine the first particle size peak with this instrument. The second peak corresponded to the particle NMD of $2.2 \mu \mathrm{m}$ and a GSD of 1.5. These values were obtained by fitting a log-normal size distribution to the data by iteration. 


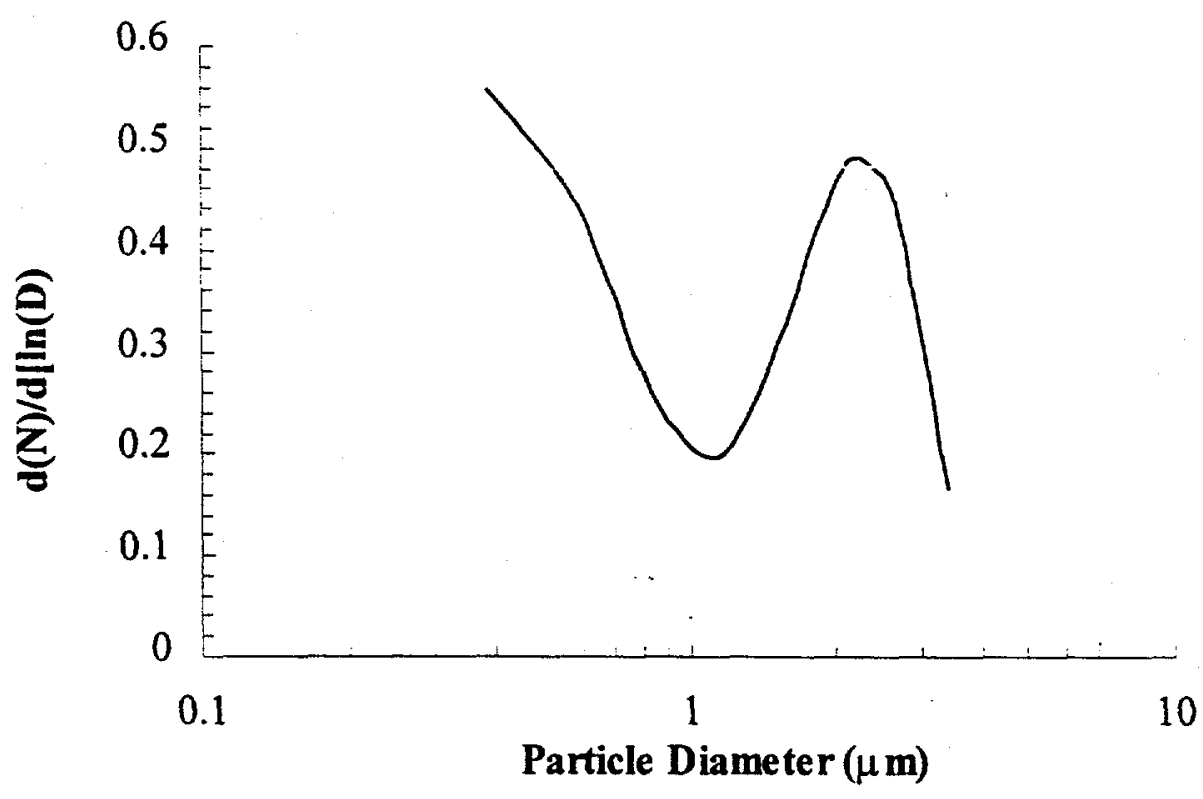

Figure 3. Particle size distribution by number for the hollow concrete surrogates with no-suppression conditions.

\subsubsection{Particle Mass and Size Distribution}

The graph between the mass (or fractional mass) of particles per unit logarithmic size interval and the logarithm of particle size should exhibit a normal distribution with a mass median diameter (MMD) and a GSD. The MMD of an aerosol is related to the NMD by:

$$
\mathrm{MMD}=(\mathrm{NMD})[\exp \{3(\ln (\mathrm{GSD}) \hat{2})\}]
$$

The NMD or the MMD can be determined by plotting the cumulative percentage of the number (or mass) of particles of greater than the stated size against size on log-probability graph and by then finding the size corresponding to 50 percent number (or mass). The GSD is obtained by dividing the size corresponding to 16 percent number (or mass) in this graph by the size corresponding to 50 percent number (or mass).

A plot of the particle diameter and particle mass per logarithmic size interval is presented in Figure 4. This was obtained by multiplying the ordinate values presented in Figure 3 by the cube of the respective diameters. It should be noted that only one peak appears in this figure. This phenomenon occurs because particles with small diameters make a less significant contribution to the mass. The mode of the mass distribution curve appears at approximately $3 \mu \mathrm{m}$. The MMD can be calculated to be about $3.4 \mu \mathrm{m}$. 


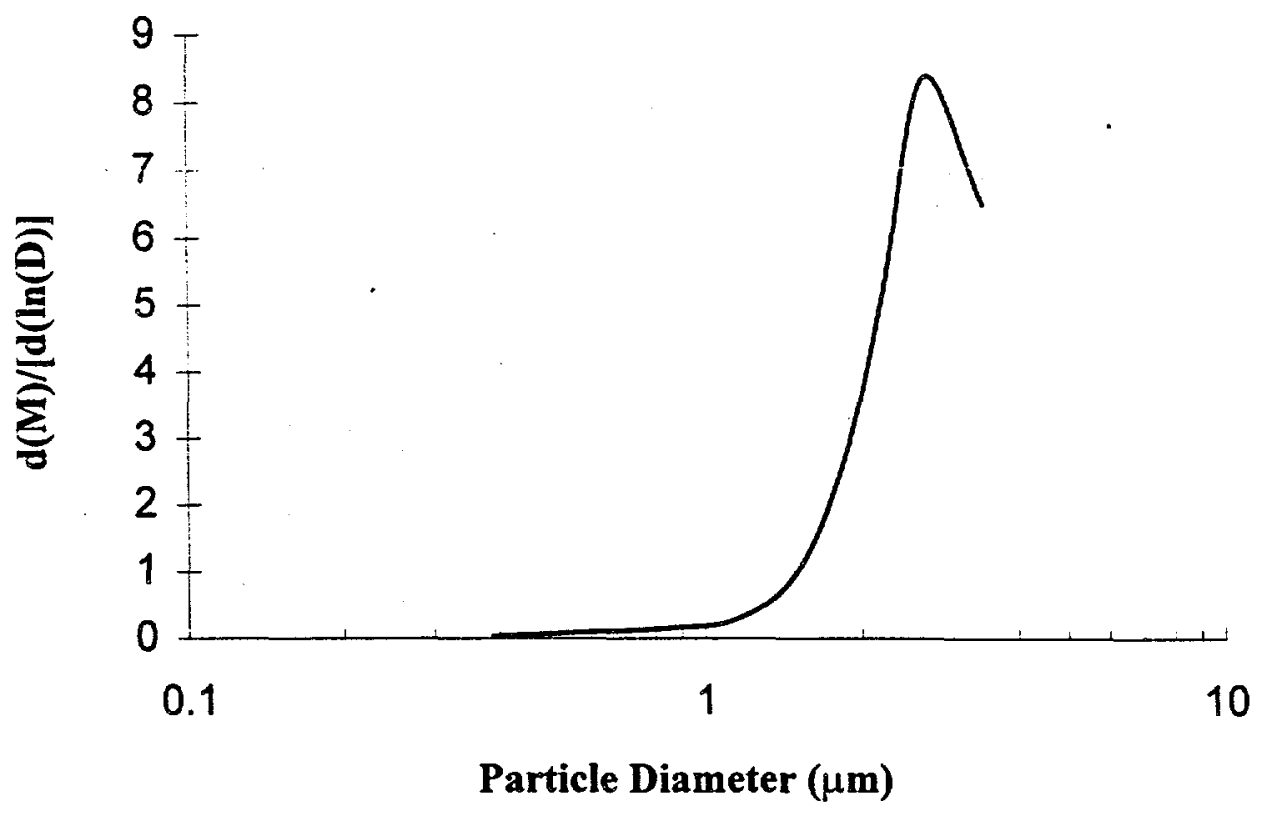

Figure 4. Particle size distribution by mass for the hollow concrete surrogates with no-suppression conditions.

\subsubsection{Data Correlations}

To predict the total number of particles generated in various particle size ranges for various loads impacting concrete blocks, a correlation between particle size, impact momentum, and number of particles per unit logarithmic size interval was developed. Impact momentum is defined as the product of the mass of the impacting body and its velocity at the time the body hits the block. The velocity, $\mathrm{V}$, is a function of the height from which the mass falls. For a free fall,

$$
\mathrm{V}=\sqrt{(2 \mathrm{gh})}
$$

where $\mathrm{g}$ denotes the acceleration due to gravity and $\mathrm{h}$ represents the height of the falling mass.

Figure 5 is a three-dimensional (3D) correlation curve obtained by using the software TableCurve $3 D$ version 2.0 (Jandel 1993a; 1993b). It can be observed that the generated particle number increases with the impact momentum. For a given impact, it varies with size, being the highest for a small size $(\sim 0.3 \mu \mathrm{m})$, then decreasing with size, and later increasing until a peak is reached at about $2.2 \mu \mathrm{m}$. Beyond this size, the particle number per unit logarithmic size interval decreases as can be predicted from the log-normal distribution. 
Plastered 8" Block, No Suppression, Wind

Rank 15 Eqn $23566843 z=a+b x^{2} .5+c x^{3}+d(\mid n y)^{2}+e y 0.5+f n y+g \| n y+h y^{2}$

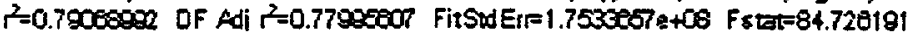

$=1.0054298 \mathrm{e}+14 \mathrm{~b}=-4709.25140=467.48718 \mathrm{~d}=-1.302534 \mathrm{e}+11$

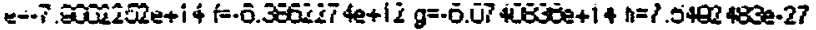

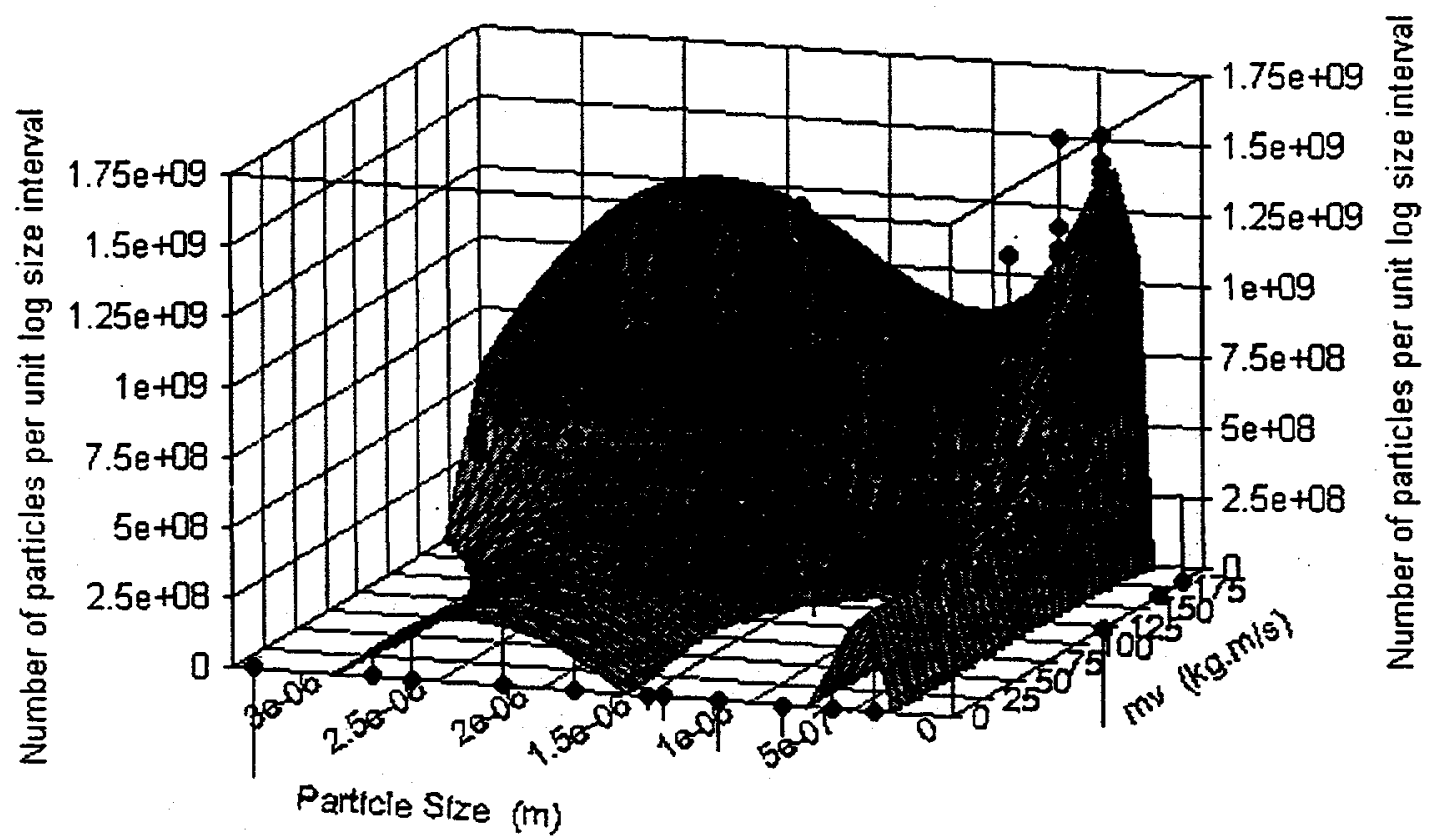

Figure 5. Mathematical correlation for particle number for the hollow concrete surrogates with no-suppression conditions.

A correlation between particle size, impact momentum, and particle mass per unit logarithmic size interval is presented in Figure 6. It can be observed that the maximum particle mass occurs at one size (close to $3 \mu \mathrm{m}$ ) only. This is due to the fact that the mass varies as the cube of particle diameter and small particles make a smaller contribution to the total mass. 
Plastered 8" Block, No Suppression, Wind

Rank 1 Eqn $2012 z=a+G A U S S X(b, c, d)+G A U S S Y(e, f, g)+G A U S S X(h, c, d) * G A U S S Y(1, f, g)$

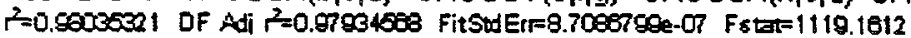

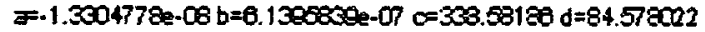

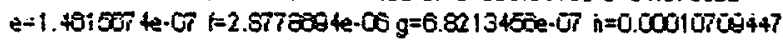

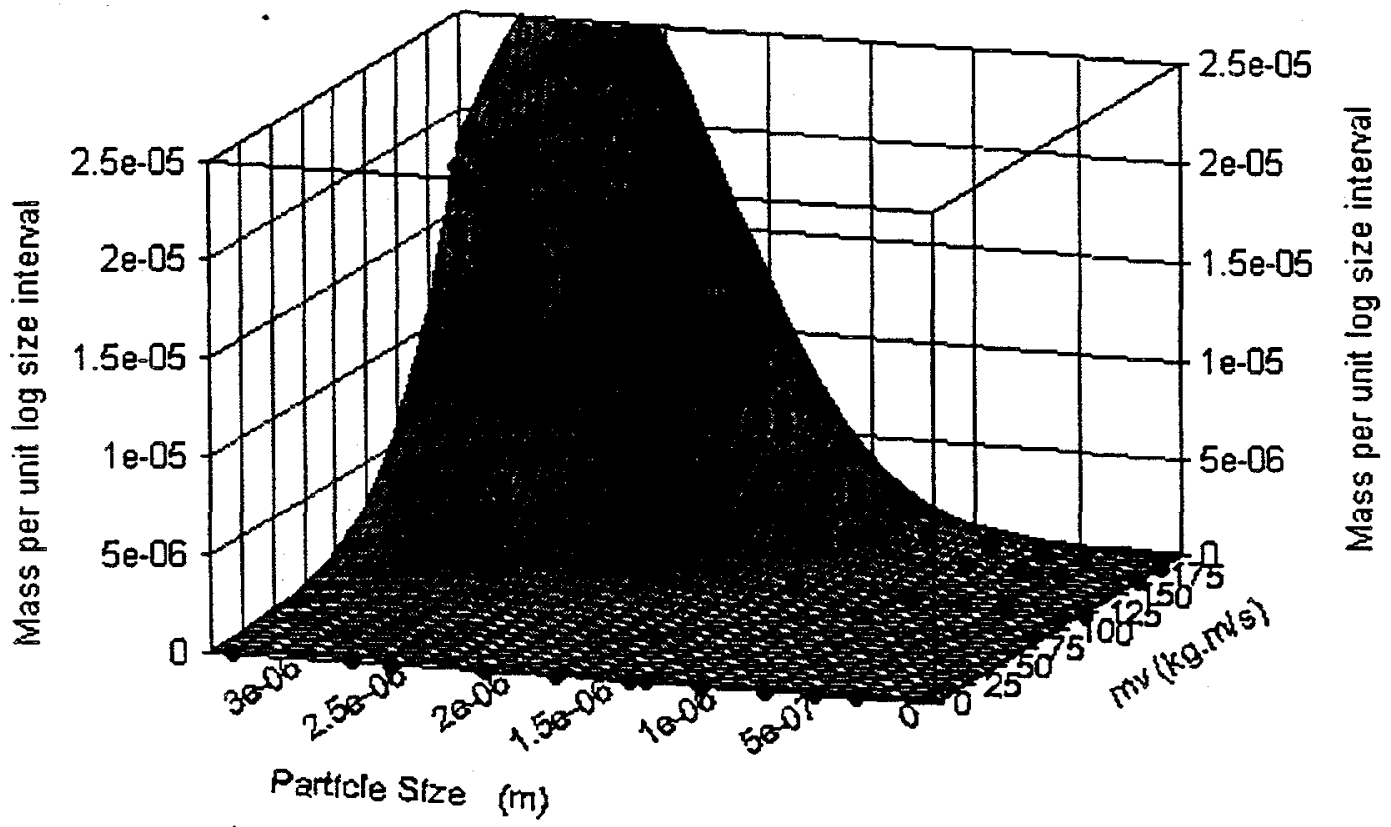

Figure 6. Mathematical correlation for particle mass for the hollow concrete surrogates with no-suppression conditions.

Figures 5 and 6 also provide the expression for the number (or mass) of particles per unit logarithmic size interval, $Z$, for impact momenta, $X$, in the range of 875 to $1330 \mathrm{lb} . \mathrm{ft} . \mathrm{s}^{-1}$ (121 kg.m.s ${ }^{-1}$ to $184 \mathrm{~kg} \cdot \mathrm{m} . \mathrm{s}^{-1}$ ) and particle diameters $(\mathrm{m}), \mathrm{Y}$, above $3 \times 10^{-7} \mathrm{~m}$. These momenta correspond to heights of $7.6 \mathrm{ft}$. to $17.4 \mathrm{ft}$. for a $39.7 \mathrm{lb}$. block. Predicted particle number (or mass) for other heights can be obtained using direct substitution into the given equation for $Z$, where $a, b, c, \ldots$ are regression constants and $r^{2}$ is the coefficient of regression. The closer $r^{2}$ is to unity, the better the correlation.

Using the expressions presented in Figures 5 and 6 and the dust suppression values shown in Tables 2 and 4, it is possible to predict the number (and mass) of the total (as well as in each size range) particulate matter generated with and without the application of a dust suppression method.

\subsection{COST ANALYSIS}

The cost analysis for the different techniques used for dust suppression is presented in Appendix A. It can be observed that the most economical method involves the technique of soaking the blocks in water. Another method that is very efficient as well as inexpensive is the technique 
involving the spraying of water during demolition. The Polymeric Barrier System is the most expensive.

\subsection{ACCOMPLISHMENTS}

The dust suppression potential of different suppression agents has been studied. The refinements of the test procedure and the data acquisition and retrieval capability used in FY96 enabled the continuous measurement of the dust concentration in the chamber. Wet suppression methods have been found to be more effective than the dry methods. As the ratio of the number of particles in various size ranges is important for determining deposition in the human respiratory tract, this ratio has been measured for various suppression methods. The dust suppression capability of the different agents has been determined for various particle sizes.

This important study can aid in the selection of size-specific dust suppressing methods for use during decontamination and decommissioning activities. Particle size distribution, an important parameter in estimating inhalation exposures, has been determined. The effect of different impacts of falling mass on concrete blocks in dust generation has been studied, and correlations have been developed. A mass correlation (see Figure 6) in various size ranges, which is important for inhalation risk assessment, has also been developed. A cost analysis of the various dust suppression methods was performed to identify an effective and inexpensive dust suppression method. This analysis is presented in Appendix A. 
REFERENCES

Jandle Scientific, 1993a, TableCurve 3D6 v. 1.0 User's Manual, Janie Scientific, San Rââel, CA.

Jandle Scientific, 1993b, TableCurve 3D6 v. 1.0, Jandle Scientific, San Rafael, CA.

Mercer, T.T., 1973, Aerosol Technology in Hazard Evaluation, Academic Press, New York.

33 United States Congress 1251 - 1376, Clean Water Act, 1990.

42 United States Congress 7401 - 7226, Clean Air Act, 1990.

SUGGESTED READING

Mody, V. and Jakhete, R., 1988, Dust Control Handbook, No Yes Data Corporation, New Jersey pp. 54-62.

18 


\section{APPENDIX A}

Table A1.

Cost Analysis for Dust Suppression

\begin{tabular}{|c|c|c|c|}
\hline Dust Suppressing Agent & $\begin{array}{l}\text { Quantity of Material } \\
\text { used per Block (gal) }\end{array}$ & $\begin{array}{l}\text { Cost per Liter of } \\
\text { Material (\$) }\end{array}$ & $\begin{array}{l}\text { Total Cost per } \\
\text { Block (\$) }\end{array}$ \\
\hline Polymeric Barrier System & 0.66 & 20.00 & 1.32 \\
\hline \multirow{2}{*}{$\begin{array}{l}\text { Coherex brushed and dried } \\
\text { (Coherex-to-water ratio } 1: 4 \text { ) }\end{array}$} & Coherex 0.026 & 1.55 & \multirow[t]{2}{*}{0.04} \\
\hline & Water 0.106 & 0.0026 & \\
\hline \multirow{2}{*}{$\begin{array}{l}\text { Coherex soaked in water and dried } \\
(\text { Coherex-to-water ratio } 1: 10)\end{array}$} & Coherex 0.022 & 1.55 & \multirow[t]{2}{*}{0.035} \\
\hline & Water 0.218 & 0.0026 & \\
\hline \multirow{2}{*}{$\begin{array}{l}\text { Coherex soaked in water } \\
(\text { Coherex-to-water ratio } 1: 10)\end{array}$} & Coherex 0.022 & 1.55 & \multirow[t]{2}{*}{0.035} \\
\hline & Water 0.218 & 0.0026 & \\
\hline Water soaked & 0.240 & 0.0026 & 0.0006 \\
\hline \multirow[t]{2}{*}{ Soap soaked } & Soap 0.009 & 7.95 & \multirow[t]{2}{*}{0.072} \\
\hline & Water 0.231 & 0.0026 & \\
\hline Water sprayed & 7.926 & 0.0026 & 0.021 \\
\hline
\end{tabular}

